\title{
Importance of Generic Skills in Accounting Education: Evidence from Egypt
}

\author{
Amani Hussein \\ Business Department, The British University in Egypt, Cairo, Egypt \\ E-mail: Amani.Hussein@bue.edu.eg
}

Received: August 30, 2017 Accepted: September 11, 2017 Published: October 10, 2017

doi:10.5296/ijafr.v7i2.11782 URL: https://doi.org/10.5296/ijafr.v7i2.11782

\begin{abstract}
Nowadays, globalization, new economic challenges and innovations in information technologies (IT) influenced the role and domain of professional accountants. The current accreditation requirements and educational frameworks of the contemporary accounting profession emphasize the importance of broad 'generic skills'. This research aims to fill the gap in studying generic skills in Egypt by examining the importance of generic skills in accounting education. The research results are consistent with the International Education Standard IES 3 and several studies, and highlighted the importance of five factors: intellectual and communication, interpersonal, creative ability, organization, research and analytical skills. Moreover, it is recommended that universities in Egypt should reevaluate their accounting education process and establish strong links with professional accounting firms.
\end{abstract}

Keywords: generic skills, intellectual skills, communication skills, interpersonal skills, organization skills

\section{Introduction}

Nowadays, globalization, new economic challenges and innovations in information technologies (IT) have influenced the role and domain of professional accountants. Accountants may support management in monitoring the operations of businesses. Other accountants assist in compliance with tax and regulatory requirements and provide information reporting needed in dynamic business environment.

One of the major objectives of accounting education is to provide competencies to students to have a successful professional life (Mcvay, Murphy, \& Wook Yoon, 2008). Pathways Commission (2012), which was created by the American Accounting Association (AAA) and the American Institute of Certified Public Accountants (AICPA) to study the future structure 
of higher education for the accounting profession, highlighted that in order to be competent, accountants must have both technical knowledge and professional skills.

Skills that are acquired, or should be acquired, during the undergraduate education can be broadly split between subject specific skills (Technical skills) and generic skills(Crawford, Helliar, \& Monk, 2011). The term generic skills has been widely used in the accounting education literature (Albrecht and Sack (2000); Kavanagh and Drennan (2008); Lin (2008); Jackling and De Lange (2009); Wells, Gerbic, Kranenburg, and Bygrave (2009); Bui and Porter(2010)). Abayadeera and Watty (2016:p149) define generic skills as those capabilities required by graduate accountants for employability and career advancement. Other authors De Lange, Jackling, and Gut (2006) referred to generic skills as the skills that capture transferrable qualities to suit the industry in which graduates work; these include but are not limited to, communication, team skills, leadership, problem solving, analytical and interpersonal skills.

The current accreditation requirements and educational frameworks of the contemporary accounting profession give emphasis to the importance of broad 'generic skills' Boyce, Greer, Blair, and Davids (2012). The International Education Standard (IES 3): Professional Skills and General Education published by the International Federation of Accountants highlighted the significance of its members being equipped with the appropriate mix of skills (intellectual, technical, personal, interpersonal and organizational) to function as professional accountants in an increasingly complex and demanding environment (IAESB, 2015). Moreover, the Pathways commission (2012) emphasized that accounting educators have responsibility to develop student's necessary professional skills taking into consideration both the dimensions of what they teach and how they teach.

The issue of generic skills has attracted substantial discussion in the academic literature in different developed and developing countries (Jackling and De Lange (2009); Kavanagh and Drennan (2008); Awayiga, Onumah, and Tsamenyi (2010); Bui and Porter (2010); Abayadeera and Watty (2016)). Although all of these studies acknowledged the importance of generic skills, the majority of them identified a skills expectations gap, where accounting educators are focusing on the development of technical skills at the expense of generic skills.

Although in Egypt there has been little research that focused on any one of these generic skills, studies by Nokhal and Ismail (2014); and Elsaadani (2015) examined "the information technology skills". There is an urgent need to develop the main skills requirement for today's accounting students that will enhance their competitive capabilities. In spite of this, an exhaustive search of the existing literature has led the researcher to conclude that there is no research in Egypt that explores different types of generic skills. Thus, this research aims to fill this gap by examining the importance of generic skills in accounting education in Egypt.

The research structure will be as follows: the next section covers a literature review, while the third section clarifies the research methodology. A comprehensive analysis regarding research results will be covered in section four, and finally, the conclusion and recommendation. 


\section{$\triangle 1$ Macrothink}

\section{Literature Review}

\subsection{Generic Skills Categories}

The International Education Standard (IES3) proposes the learning outcomes for professional skills that are required by the end of Initial Professional Development (IPD). Professional skills are the (a) intellectual, (b) interpersonal and communication, (c) personal, and (d) organizational skills that a professional accountant integrates with technical competence and professional values, ethics, and attitudes to demonstrate professional competence. IES clarified these categories as follows (IAESB, 2015).

(a) Intellectual relates to the ability of a professional accountant to solve problems, to make decisions, and to exercise professional judgment;

(b) Interpersonal and communication relate to the ability of a professional accountant to work and interact effectively with others;

(c) Personal relates to the personal attitudes and behavior of a professional accountant; and

(d) Organizational relates to the ability of a professional accountant to work effectively with or within an organization

Different terms were used to describe such generic skills in the literature include "professional", "soft", "key" or "core" "capabilities" and "competencies" .

Table 1. Generic skills in IES, prior studies and this research

\begin{tabular}{|c|c|c|c|}
\hline Kavanagh and Drennan (2008) & Mandilas et al. (2014) & This International Education Standard (IES3) & This research \\
\hline Personal and communication & Social Skills & Intellectual: & Oral Communication skills \\
\hline $\begin{array}{l}\text { Written communication } \\
\text { Teamwork }\end{array}$ & $\begin{array}{l}\text { Knowledge of basic computer } \\
\text { tools (internet, office programs) }\end{array}$ & $\begin{array}{l}\text { Apply reasoning, critical analysis, and innovative } \\
\text { thinking to solve problems. }\end{array}$ & $\begin{array}{l}\text { Written Communication skills } \\
\text { Ability to take initiatives }\end{array}$ \\
\hline Oral communication & Oral communication skills & Recommend solutions to unstructured, multi-faceted & A bility to apply theoretical \\
\hline Values & Written communication skills & problems. & $\begin{array}{l}\text { Ability to apply theoretical } \\
\text { knowledge }\end{array}$ \\
\hline Tenacity & Ability to integrate in a company & Interpersonal and communication: & Ability to apply practical \\
\hline Work ethic & Ability to appreciate different & Display cooperation and teamwork when working & $\begin{array}{l}\text { Aointy to apply practical } \\
\text { knowledge }\end{array}$ \\
\hline Problem solving & points of view (empathy) & towards organizational goals & Ability to think logically \\
\hline Cultural sensitivity & Ability to take initiative & Communicate clearly and concisely when presenting, & $\begin{array}{l}\text { Ability to think logically } \\
\text { Ability to think critically }\end{array}$ \\
\hline Cross-cultural communication & Methodological skills & discussing and reporting in formal and informal & Problem solving skills \\
\hline Cultural sensitivity & Ability to apply theoretical & situations, both in writing and orally. & Time management \\
\hline $\begin{array}{l}\text { Cross-cultural appreciation } \\
\text { Foreign language }\end{array}$ & $\begin{array}{l}\text { knowledge. } \\
\text { Ability to apply practical }\end{array}$ & $\begin{array}{l}\text { Personal } \\
\text { Apply consultative skills to minimize or Personal }\end{array}$ & $\begin{array}{l}\text { Information analysis and } \\
\text { interpretation }\end{array}$ \\
\hline Leadership and interpersonal & knowledge & Demonstrate a commitment to lifelong learning. & Information compilation skills \\
\hline $\begin{array}{l}\text { Leadership } \\
\text { Negotiation }\end{array}$ & $\begin{array}{l}\text { Ability to think logically } \\
\text { A bility to think critically }\end{array}$ & $\begin{array}{l}\text { Apply professional skepticism through questioning and } \\
\text { critically assessing all information. }\end{array}$ & Skills for documenting ideas and \\
\hline Interpersonal & Problem solving skills & Manage time and resources to achieve professional & Tonnnnart obilitzo \\
\hline Measurement & Ability to adapt to new situations & commitment & $\begin{array}{l}\text { leamwork abillty } \\
\text { Ability to make decisions and }\end{array}$ \\
\hline Promotional & Creative ability & Organizational & inter to monsibilities \\
\hline $\begin{array}{l}\text { Self-promotion } \\
\text { Company promotion }\end{array}$ & $\begin{array}{l}\text { Ability to administer time } \\
\text { correctly }\end{array}$ & $\begin{array}{l}\text { Undertake assignments in accordance with established } \\
\text { practices to meet prescribed deadlines. }\end{array}$ & assume responsibilities \\
\hline $\begin{array}{l}\text { Analytical and design } \\
\text { Resource management }\end{array}$ & $\begin{array}{l}\text { Information analysis and } \\
\text { interpretation skills }\end{array}$ & $\begin{array}{l}\text { Apply people management skills to motivate and } \\
\text { develop others. }\end{array}$ & Meeting tight deadline \\
\hline Research & Information compilation skills & Apply leadership skills to influence others to work & Computer technology competence \\
\hline Risk analysis & Skills for documenting ideas and & towards organizational goals. & Accounting software competence \\
\hline Appreciative & decisions & Apply appropriate tools and technology to increase & \\
\hline Critical thinking & Participation skills & efficiency and effectiveness and improve decision & \\
\hline Analytical & Teamwork ability & making & \\
\hline Continuous learning & $\begin{array}{l}\text { Ability to make decisions and } \\
\text { assume responsibilities } \\
\text { Ability to work under pressure } \\
\text { Leadership ability }\end{array}$ & & \\
\hline
\end{tabular}


In addition, these skills dominate the literature although they may be grouped differently by different authors. A study by Wells et al. (2009) highlighted the importance of personal, intellectual and interpersonal aspects of professional capabilities to be successful in the workplace. In another study, Kavanagh and Drennan (2008) classified the generic skills into personal and communication, analytical and design and appreciative. Moreover, Mandilas, Kourtidis, and Petasakis (2014) in their study classified generic skills into three main categories social skills, methodological skills and participation skills. However Webb and Chaffer (2016) classified the generic skills into personal skills: inter-personal, leadership inter-personal, communication, appreciative, learning and written communication. Table (1) presents a summary of the skills' main categories and its items as identified in IES3 and some of the aforementioned studies, revealing a degree of overlap among them. In addition, table (1) shows the list of skills included in this research.

\subsection{Importance of Generic Skills}

Several studies highlighted the importance of generic skills even more than technical skills in both developed and developing countries. Kavanagh and Drennan (2008) conducted a study involving data collection from 322 graduating students in three universities in Australia and 28 practitioners in a number of organizations and industries. The respondents were required to rate 47 specific skills/attributes. Eight factors appeared and were labelled: personal and communication, cultural sensitivity, interpersonal and leadership, promotional, analytic/design, appreciative, routine accounting, and ethics. Although both groups acknowledged the importance of analytical/problem solving skills, oral and written communication skills, teamwork and continuous learning, there were differences in terms of how each group ranks each skill.

Moreover, Jackling and De Lange (2009) examined graduates' perceptions of the content of their undergraduate accounting course. Data was obtained from 174 graduates from an Australian university. The results indicated that team skills, leadership, and oral communication are the skills most desired. Interestingly, the 'key accounting and associated skills were 'ranked fifth in terms of skills for career progression whereas 'communication skills' ranked first and 'problem-solving' skills ranked second categories. The overall results show that graduates perceive various generic skills as being amongst the most required for a successful accounting career.

In developing countries, the same conclusions have been reached in China by Lin (2008) who adopted the Albrecht and Sack (2000) survey instrument with 37 items of knowledge and skills identified as the variables for the research factor analysis. The results revealed six factors that summarized varied dimensions of the knowledge and skills of the respondents' opinions. Two of these factors were related to skills. One factor was defined as business/management skills, including leadership, analytical and critical thinking, change management and customer-orientation. The other factor was classified as "personal skills" including ethics and social responsibility, oral and written communication and teamwork. The study's main conclusion indicated that professional skills should be given high priority in accounting education, may be greater than accounting knowledge in China or possibly other 
countries.

Moreover, Awayiga et al. (2010) conducted a study in Ghana using a sample of 131 graduates and 25 practitioners. The results indicated that the least important skills as rated by the graduates are technical and functional skills. Another study conducted in Sri Lanka examined the gap between accounting undergraduates' perceptions and practitioners' perceptions on the importance of generic skills to career success. A total of 247 responses were analyzed and extracted using factor analysis resulting in five factors grouped into the following order: management skills and work experience; intellectual skills and personal qualities; analytical skills; communication skills and accounting and technical skills. The main finding was the importance of including generic skills in accounting curricula (Abayadeera \& Watty, 2016).

Although the studies that investigated the generic skills agree on the importance of these skills to one's professional career, there were variations among them in skills list and rank of skills importance. These variations may have happened due to sample size, type of respondent, the country where the study was conducted and the study period. Therefore, the following paragraphs review some of the most important studies in this area.

A study conducted in US by Albrecht and Sack (2000) using 22 skill items asking respondents whom were educators and practitioners to assess which skills they believed were most important in terms of time devoted in developing it. They ranked skills based on importance as follows starting with analytical/critical thinking, written communications, oral communications, computing technology, decision making, interpersonal skills, continuous learning, teamwork, and last skill was foreign language. Interestingly, educators and practitioners agreed as to which are the most important skills.

In a study in China Lin, Xiong, and Liu (2005) examined whether there was any significant difference in the perceptions between 181 accounting practitioners, 43 accounting faculty members, and 845 students concerning knowledge and skills to be incorporated into accounting curriculum. They adapted the survey instrument from the Albrecht and Sacks (2000) study of the future of accounting education in the US. The result indicated the importance of analytical and critical thinking, written communication, oral communication, and decision-making skills that are recognized in the US studies as the most important skills, whereas the Chinese respondents gave these skills relatively lower ratings.

Another study was conducted in Australia by De Lange et al. (2006) that surveyed 310 graduates from two universities in Victoria to know their opinions on the importance given on the development of those generic skills in the accounting curriculum. The respondents specify a lack of importance on the majority of the generic skills desired by the profession, especially interpersonal, oral communication and computing/information technology skills. All graduates considered communication skills (oral, written, and interpersonal) and teamwork to be essential. Also, they pointed out that students must be involved in teamwork during their university education.

Other studies emphasized the importance of analytical, oral and written communication skills such as (Crawford et al., 2011). Another study was conducted in Northern Greece using a 
sample of 166 students, 25 lecturers/professors of the Accounting and Finance Department at TEI Kavala, and 155 companies. The study applied factor analysis and revealed five factors. According to the questionnaire survey, departments have to focus on skills and knowledge, and mainly on the following: general culture, oral communication skills, written communication skills, public speaking skills, ability to think critically, and ability to work under pressure, and personal fit with the company's image. (Mandilas et al., 2014)

Andrews and Higson (2008) analyzed the perceptions and experiences of business graduates and accounting practitioners in four European countries (UK, Austria, Slovenia and Romania). Utilizing semi-structured interview techniques, a total of fifty people were interviewed across all four countries, thirty business graduates and twenty practitioners. A number of skills were included in the study such as; the ability to work under pressure; the ability to plan and think strategically; the capability to communicate and interact with others, either in teams or through networking; good written and oral communication skills; information and communication technology skills; time-management skills and a willingness to learn and accept responsibility. The findings revealed that all respondents agree on four skills as the most important in shaping graduate employability, namely written and oral communication skills; team-working skills and problem-solving abilities. Moreover, another study done in the UK supports the same conclusion in addition to considering time management as an important skill. (Towers-Clark, 2015)

Webb and Chaffer (2016) in their study applied factor analysis with a total sample size of 884 UK graduates. The results revealed six factors labelled: Personal; Inter-personal (Leadership); Inter-personal (Communication); Appreciative; learning and the last factor written communication. Another study in the UK was conducted by Hegazy, Sangster, and Kotb (2017) who collected their data through four in-depth interviews with 262 heads of forensic services departments/firms in UK. It was prepared with open-ended questions that allowed respondents to freely reveal detailed aspects of the issues. All skills listed in the study were considered essential by over $90 \%$ of those who responded. However, the most critical skills of forensic accountants were identified as communication skills and analytical skills, followed by problem solving and investigative skills.

Wally-Dima (2011) examined a group of skills using a 12 lecturers and 30 accounting and auditing firms. The results indicated six highly ranked skills as follow: business decision making; leadership; computer technology, decision making, interpersonal skills and analytical/critical thinking. In addition, oral communication and risk analysis are considered less important for skill development. However in another study conducted in Malaysia analytical, critical thinking, risk analysis, and oral communication were considered as the most important skills. There were differences in ranking of some skills, such as risk analysis, between practitioners who ranked it as third in importance and educators who ranked it as eighth in importance (Ali, Kamarudin, Suriani, Saad, \& Afandi, 2016)

Some of the studies focus on certain important types of generic skills. Such as communication skills and information technology (IT) skills. The importance of communication skills for accountants has been emphasized in the literature for more than 50 
years. Siriwardane and Durden (2014) critically review 19 studies published between 1972 and 2012 to investigate the written and/or oral communication skills of practicing accountants. In the studies they found, oral communication skills were commonly ranked by practicing accountants as being more important than written communication skills. Another key differences in the views of educators and practitioners that was evident from the 19 studies were educators placed greater emphasis on formal communication (both oral and written), while practitioners placed greater emphasis on informal communication. Another study focused more on knowing what criteria were actually used in the hiring process. Over the last 20 years, effective communication, organizational, and interpersonal skills are consistently cited in reports as requirements for success in the accounting profession. Further analysis of the data set collected from the three regions Chicago, New York City, and Washington DC indicated that effective communication skills were the most required. However, these results must be interpreted cautiously because only 23 newspaper advertisements from CPA firms and 30 from Internet position announcements for firms were used during the study period (Normand \& Cummings, 2015)

Ahadiat and Martin (2016) in their study reached the same conclusion that communication skills are among the most important criteria for selecting accounting employees. Moreover, Riley and Simons (2016) pointed out that it is imperative that accounting educators incorporate written communication skills in the accounting curriculum.

Academic thought general knowledge of Information Technology (IT) is important, while practitioners thought competence as a user of information system is important (Pratama, 2015). In their study in Bahrain, Sarea and Alrawahi (2014) compare the views of undergraduate students before they join the workforce and views of practitioners who have already joined the workforce. Key difference between the two groups concern (IT) skills. Students rated IT as the 5th most important skill conversely, practitioners rated IT as the 10th most important skill.

Few studies were conducted in Egypt focusing on one type of generic skill, namely IT skills. One of these was the research of Nokhal and Ismail (2014) which aimed at identifying the IT Knowledge /skills required for accounting students as perceived by accounting lecturers in Egypt. Based on a sample of 249 accounting lecturers in Egypt, the research findings showed that most accounting lecturers perceived that IT knowledge and skills should be integrated into accounting curriculum in Egypt. Another research study in Egypt took place during the period from August 2014 to February 2015 to examine the level of sufficiency of Information and communication technology (ICT) skills of fresh accounting graduates. The participating business organizations were located in the city of Alexandria, Egypt. A total of 234 questionnaires were distributed, but only 188 were collected. Senior accounting staff reported that they focus on selecting the graduates of private higher education institutions, and they may select among the graduates of governmental accounting higher education institutions only if the candidates are well prepared and trained during or after graduation to use the necessary ICT skills. (Elsaadani, 2015) 


\subsection{Skill Development Opportunities}

Accounting educators should adapt an approach that improves skills such as analytical/critical thinking, written communication, oral communication, computing technology, decision making, interpersonal skills, continuous learning, teamwork, leadership, risk analysis, and accounting packages. Under a superficial approach, the student perceives the subject material as only needing to be memorized for the exam. Whereas under the deep approach, the student attempts to grasp the concepts and ideas to form a background for the subject area. The deep approach enable accounting education to provide students with the communication, interpersonal and intellectual skills that prepare them for business in today's global environment. Accounting education should provide students not only with the knowledge and skills required, but also with the know-how that enables students to apply those skills. (Mohamed \& Lashine, 2003)

Crawford et al. (2011) in their study indicated that both practitioners and academics share similar views on the importance of teaching generic skills. To meet this need, a skill improvement approach should be integrated into accounting education. Students should participate in the learning process and develop skills such as creative and critical thinking Kavanagh and Drennan (2008). This could be achieved through applying innovative teaching methods such as case analysis, roleplaying, analysis of information, real company-assignments, and technology assignments. (Lin et al., 2005)

There is a need for greater understanding of accountant-client interactions as well. While group work and presentations have been the focus of oral communication skills development in accounting education, role plays with feedback provide successful approach to teaching interpersonal communication skills. (Daff, 2012)

Pathway Commission's report (2012) clarifies that today's students had access to the Internet and personal electronics, resulting in new skills and learning patterns. Thus to acquire high potential, great effort should be placed to provide students with project-based learning and take advantage of technology. Moreover, some critical thinking learning objectives are better achieved with students working in diverse groups and keeping the project as unstructured as possible. Also, students are encouraged to seek outside help and consulting with experts. (Sergeant \& Camion, 2016)

Wally-Dima (2011) conducted a study in which accounting practitioners were asked to rank some of the methods used to develop skills in accounting programs. The relative importance was as follows: internship program in local companies, case study approaches, seminar presentation by students and seminar presentations by guest. Mohamed and Lashine (2003) pointed out that internship programs should not be treated as a mere training program but as an opportunity to work on real problems facing a business. In addition, Maelah, Aman, Mohamed, and Ramli (2012) study findings suggested that industrial training enhances three categories of skills namely communication skills, leadership and team work and self-management.

To summarize, generic skills are as important as accounting knowledge for success in the 
accounting profession. Although the studies concerned with the importance of generic skills in developed and developing countries have no agreement on well-defined skills list they agree on the significance of most of them such as oral and written communication, critical thinking, problem solving, team work, time management, risk analysis and IT skills. Moreover, the majority of the studies support integrating these skills into the university level education. Thus, the experience of accounting education developments in other countries has become important and valuable source for the development of accounting education in Egypt.

\section{Research Methodology}

\subsection{Research Approach}

To achieve the objectives of the research, a questionnaire was developed and distributed on a sample of accounting professionals and students to measure their opinions on the importance of generic skills in accounting education. The research explored the opinions of professionals and students on the importance of each skill item through some descriptive statistics. Then, a comparison was conducted between the opinions of professionals and students using independent samples t-tests to examine whether they perceive the importance of components in different ways. To build a well-defined set of constructs that determine items needed to be included in accounting education, factor analysis is implemented. The broad purpose of factor analysis is to summarize data so that relationships and patterns can be easily interpreted and understood. It is normally used to regroup variables into a limited set of clusters based on shared variance. (Yong \& Pearce, 2013) Thus, applying factor analyses can capture the interrelationship and summarize a large group of variables into a smaller set of factors of the desired skill items.

\subsection{Data Collection and Generic Skills List}

The list of generic skills included in this research was developed with reference to IES 3: Professional Skills and General Education (International Accounting Education Standards Board, 2015) and also with reference to the skills identified in previous literature Kavanagh and Drennan (2008), Jackling and De Lange (2009) and Mandilas et al. (2014) some skills identified in these sources were excluded as some are more technical such as basic accounting skills. A pre-test for the questionnaire was done by two accounting lecturers and three accounting professionals to be more consistent with the Egyptian environment. The questionnaire was subsequently revised based on feedback. To increase the response rate, mainly structured closed questions are used. As a result, a total of 21 skills are identified as variables for the factor analysis and shown in Table (1).

The questionnaire aimed to measure the importance of each skill item based on a scale from 1 to 5 , where 1 referred to the lowest score of importance and 5 referred to the highest score of importance.

Two groups of respondents were selected to answer the questionnaires; the first group were the professional accountants who were the best judges because, they are the ones who apply these skills in their profession. The majority of the professionals, 85\%, were from Big auditing firms in Egypt (i.e. PricewaterhouseCoopers (PwC), Deloitte Touche Tohmatsu, and 


\section{Mll Macrothink}

International Journal of Accounting and Financial Reporting

ISSN 2162-3082

2017, Vol. 7, No. 2

Ernst \& Young, and Grant Thornton) and 15\% from other firms such as Arab Accounting Firm. These accounting firms were contacted by telephone, email and frequent personal visits. A total of 119 usable out of $200(60 \%)$ were the actual complete questionnaires returned.

The second group, were final year accounting students in 2016 studying in six private Egyptian universities (British University in Egypt (BUE), Germen University in Cairo (GUC), American University in Cairo (AUC), Misr International University (MIU), Misr University Science \& Technology (MUST) and Modern Science \& Art (MSA). Selecting a sample of students was based on Kavanagh and Drennan (2008) justification that students are a key stakeholder group when it comes to examining views about developing skills for a career since students' incentives to acquire skills are motivated by the importance of these skills to their careers. A total of 126 usable out of 200 (63\%) questionnaires were collected from students. Incomplete questionnaires with missing answers were discarded. The questionnaires for the two groups were the same except a question concerning practitioners' level of experience and another for students asking for their Grade Point Average (GPA)

The research aim was at measuring the importance of 21 generic skills in accounting education in Egypt. This was fulfilled through answering the following research questions

Q1: Is there any differences in importance of generic skills items between Egyptian professional accounting and accounting students?

Q2: What are the most important generic skills?

\section{Data Analysis and Results}

The research results start with description of research sample as shown in Table 2 .

Table 2. Description of the sample

\begin{tabular}{|c|c|c|c|c|c|c|}
\hline \multirow{5}{*}{$\begin{array}{l}\text { Professionals } \\
\text { Total Number } \\
\text { Respondents: } 119\end{array}$} & \multirow{5}{*}{ of } & \multicolumn{5}{|c|}{ Work Experience (number and percentage) } \\
\hline & & \multirow{2}{*}{$\begin{array}{l}\text { Less than a } \\
\text { year }\end{array}$} & \multirow{2}{*}{$\begin{array}{l}1-10 \\
\text { years }\end{array}$} & \multirow{2}{*}{$\begin{array}{l}11-20 \\
\text { years }\end{array}$} & \multicolumn{2}{|c|}{ more than 20 years } \\
\hline & & & & & & \\
\hline & & 8 & 79 & 24 & 4 & \\
\hline & & $7.0 \%$ & $68.7 \%$ & $20.9 \%$ & $3.5 \%$ & \\
\hline \multirow{5}{*}{$\begin{array}{l}\text { Students } \\
\text { Total Numbe } \\
\text { Respondents: } 126\end{array}$} & \multirow{5}{*}{ of } & \multicolumn{5}{|c|}{ Average Grade (number and percentage) } \\
\hline & & than & average & good & very & excellent \\
\hline & & average & & & good & \\
\hline & & 1 & 3 & 17 & 69 & 27 \\
\hline & & $0.8 \%$ & $2.4 \%$ & $13.5 \%$ & $54.8 \%$ & $21.4 \%$ \\
\hline
\end{tabular}

Table 2 gives a brief idea about the research sample. It reveals that the majority, $68.7 \%$, of the (119) accounting professional have a level of experience ranging from 1-10 years and that the majority, $54.8 \%$, of the accounting students (126) were with a very good GPA. This could be interpreted as the questionnaire are collected close to the end of the semester with a majority of good students who attend, moreover some of the questionnaires are distributed and collected during an accounting competition which included almost all very good students. 
The research explores the opinions of professionals and students on the importance of each generic skill through descriptive statistics

Table 3. Descriptive statistics

\begin{tabular}{|c|c|c|c|}
\hline Skills & $\mathbf{N}$ & Mean & Std. Deviation \\
\hline 1. Time management & 243 & 4.30 & 0.89 \\
\hline 2. Problem solving skills & 245 & 4.25 & 0.96 \\
\hline 3. Ability to work under pressure & 241 & 4.23 & 1.01 \\
\hline 4. Oral Communication skills & 244 & 4.23 & 0.94 \\
\hline 5. Teamwork ability & 244 & 4.16 & 0.97 \\
\hline 6. Ability to think critically & 244 & 4.15 & 1.02 \\
\hline 7. Ability to think logically & 245 & 4.15 & 0.98 \\
\hline $\begin{array}{l}\text { 8. Ability to make decisions and assume } \\
\text { responsibilities }\end{array}$ & 245 & 4.14 & 0.95 \\
\hline 9. Written Communication skills & 245 & 4.14 & 0.97 \\
\hline 10. Ability to apply practical knowledge & 245 & 4.14 & 1.04 \\
\hline 11. Meeting tight deadline & 244 & 4.13 & 0.99 \\
\hline 12. Leadership ability & 245 & 4.09 & 1.03 \\
\hline 13. Computer technology competence & 245 & 4.04 & 0.98 \\
\hline 14. Accounting software competence & 243 & 3.99 & 1.07 \\
\hline 15. Risk analysis & 242 & 3.98 & 1.05 \\
\hline 16. Ability to apply theoretical knowledge & 241 & 3.97 & 1.01 \\
\hline 17. Ability to take initiatives & 244 & 3.95 & 0.98 \\
\hline 18. Information analysis and interpretation & 243 & 3.90 & 0.98 \\
\hline 19. Skills for documenting ideas and decisions & 242 & 3.81 & 0.99 \\
\hline 20. Research & 239 & 3.73 & 1.16 \\
\hline 21. Information compilation skills & 244 & 3.70 & 1.00 \\
\hline
\end{tabular}




\section{Mll Macrothink}

International Journal of Accounting and Financial Reporting

ISSN 2162-3082

2017, Vol. 7, No. 2

Table 3 represents descriptive statistics of the entire sample and the mean and standard deviation for each skill item as listed in the table based on their rank order. The table revealed that 13 skill items are ranked important, however time management and problem solving skills are ranked the highest. These skills had a mean score above 4 since this research adopt the "importance" benchmark of 4 used in Kavanagh and Drennan's, (2008) study. This results are in line with prior studies. (Kavanagh and Drennan, 2008;Awayiga et al. (2010); Towers-Clark (2015)) that indicate the importance of analysis and critical evaluation skills, time management and problem-solving skills.

Table 4. Testing difference in mean scores between the professionals and the students

\begin{tabular}{|c|c|c|c|c|c|c|c|}
\hline \multirow[b]{2}{*}{ Skills } & \multicolumn{3}{|c|}{ Professional } & \multicolumn{3}{|c|}{ Student } & \multirow[b]{2}{*}{ Sign } \\
\hline & Mean & $\begin{array}{l}\text { Ran } \\
\mathrm{k}\end{array}$ & $\begin{array}{l}\text { Std. } \\
\text { Deviation }\end{array}$ & $\begin{array}{l}\text { Mea } \\
\mathrm{n}\end{array}$ & $\begin{array}{l}\text { Ran } \\
\mathrm{k}\end{array}$ & $\begin{array}{l}\text { Std. } \\
\text { Deviation }\end{array}$ & \\
\hline Meeting tight deadline & 4.14 & 1 & 0.97 & 4.12 & 15 & 1.01 & 0.84 \\
\hline Time management $* * *$ & 4.04 & 2 & 1.03 & 4.54 & 1 & 0.65 & 0.00 \\
\hline Problem solving skills*** & 4.01 & 3 & 1.09 & 4.48 & 2 & 0.76 & 0.00 \\
\hline Oral Communication skills*** & 4 & 4 & 0.98 & 4.44 & 5 & 0.84 & 0.00 \\
\hline Teamwork ability*** & 3.98 & 5 & 1 & 4.33 & 10 & 0.91 & 0.00 \\
\hline $\begin{array}{llll}\text { Ability to } & \text { work } & \text { under } \\
\text { pressure } * * *\end{array}$ & 3.97 & 6 & 1.07 & 4.48 & 3 & 0.90 & 0.00 \\
\hline Leadership ability** & 3.93 & 7 & 1.04 & 4.23 & 11 & 1.01 & 0.02 \\
\hline Ability to think critically*** & 3.92 & 8 & 1.08 & 4.37 & 9 & 0.92 & 0.00 \\
\hline Risk analysis & 3.9 & 9 & 1.14 & 4.07 & 18 & 0.95 & 0.22 \\
\hline Ability to think logically**** & 3.9 & 10 & 1.08 & 4.38 & 8 & 0.83 & 0.00 \\
\hline $\begin{array}{ll}\begin{array}{l}\text { Computer } \\
\text { competence** }\end{array} & \text { technology } \\
\end{array}$ & 3.9 & 11 & 1.04 & 4.17 & 12 & 0.92 & 0.03 \\
\hline $\begin{array}{l}\text { Accounting } \\
\text { competence** }\end{array}$ & 3.85 & 12 & 1.16 & 4.12 & 16 & 0.96 & 0.05 \\
\hline $\begin{array}{l}\text { Written } \\
\text { skills*** }\end{array}$ & 3.84 & 13 & 1.1 & 4.41 & 7 & 0.73 & 0.00 \\
\hline $\begin{array}{l}\text { Ability to make decisions and } \\
\text { assume responsibilities }\end{array}$ & 3.83 & 14 & 1.01 & 4.43 & 6 & 0.79 & 0.00 \\
\hline $\begin{array}{l}\text { Ability to apply theoretical } \\
\text { knowledge** }\end{array}$ & 3.81 & 15 & 1.03 & 4.11 & 17 & 0.98 & 0.02 \\
\hline $\begin{array}{l}\text { Ability to apply practical } \\
\text { knowledge }^{* * *}\end{array}$ & 3.8 & 16 & 1.11 & 4.45 & 4 & 0.85 & 0.00 \\
\hline $\begin{array}{l}\text { Skills for documenting ideas and } \\
\text { decisions }\end{array}$ & 3.75 & 17 & 0.95 & 3.87 & 20 & 1.03 & 0.33 \\
\hline Ability to take initiatives $* * *$ & 3.72 & 18 & 0.99 & 4.16 & 13 & 0.92 & 0.00 \\
\hline $\begin{array}{l}\text { Information analysis } \\
\text { interpretation } * * *\end{array}$ & 3.62 & 19 & 0.97 & 4.16 & 14 & 0.92 & 0.00 \\
\hline Information compilation skills* & 3.59 & 20 & 1.02 & 3.80 & 21 & 0.97 & 0.09 \\
\hline Research ** & 3.56 & 21 & 1.21 & 3.89 & 19 & 1.09 & 0.03 \\
\hline
\end{tabular}

$* * *$ Difference is significant at $1 \%, * *$ difference is significant at $5 \%$, $*$ difference is significant at $10 \%$ 


\section{MIMacrothink}

International Journal of Accounting and Financial Reporting

ISSN 2162-3082

2017, Vol. 7, No. 2

A comparison was conducted between the opinions of professionals and students using independent sample t-tests to examine whether they perceive the importance of skills items in different ways.

Table 4 indicated significant variations at 1\% exist in the perceived importance scores between the two groups of respondents related to 11 skills, for example oral and written communication, problem solving and teamwork ability. These results answer the first research question, that there are differences in both groups' opinions. Although, in some of the 11 skills they are close in their importance ranking, such as time management, problem solving skills, oral communication skills, ability to think critically, and ability to think logically, in other skills, there are big variations in ranking such as team work, written communication skills, ability to apply practical knowledge and ability to take initiatives. These results are consistent with the study of Kavanagh and Drennan (2008) that indicated some agreement between students and practitioners in terms of the importance of some skills such as analytical/problem-solving skills, oral and written communication skills and teamwork and continuous learning. However, there is a difference in terms of how each group ranks each skill. However, the study by Lin et al. (2005) the professionals gave higher rank to written communication than professional in this research.

To increase simplicity and richness to the research findings, data related to skills were further analyzed to identify latent factors. The first step before performing factor analysis was to look at the correlation between variables through creating a correlation matrix. The following table (5) illustrates the existence of significant correlations to a certain limit between the study variables which implies the suitability of applying factor analysis as mentioned by (Field, 2009). 
Table 5. Correlation matrix

\begin{tabular}{|c|c|c|c|c|c|c|c|c|c|c|c|c|c|c|c|c|c|c|c|c|c|}
\hline Skills & 1 & 2 & 3 & 4 & 5 & 6 & 7 & 8 & 9 & 10 & 11 & 12 & 13 & 14 & 15 & 16 & 17 & 18 & 19 & 20 & 21 \\
\hline $\begin{array}{l}\text { 1.Oral Communication } \\
\text { skills }\end{array}$ & 1 & & & & & & & & & & & & & & & & & & & & \\
\hline $\begin{array}{l}\text { 2.Written } \\
\text { Communication skills }\end{array}$ & 0.74 & 1.00 & & & & & & & & & & & & & & & & & & & \\
\hline $\begin{array}{l}\text { Communucation skills } \\
\text { 3.Ability to take } \\
\text { initiatives }\end{array}$ & 0.68 & 0.75 & 1.00 & & & & & & & & & & & & & & & & & & \\
\hline $\begin{array}{l}\text { 4.Ability to apply } \\
\text { theoretical knowledge }\end{array}$ & 0.61 & 0.73 & 0.70 & 1.00 & & & & & & & & & & & & & & & & & \\
\hline $\begin{array}{l}\text { 5.Ability to apply } \\
\text { practical knowledge }\end{array}$ & 0.67 & 0.70 & 0.70 & 0.76 & 1.00 & & & & & & & & & & & & & & & & \\
\hline $\begin{array}{l}\text { 6.Ability to think } \\
\text { logically }\end{array}$ & 0.65 & 0.64 & 0.65 & 0.69 & 0.82 & 1.00 & & & & & & & & & & & & & & & \\
\hline $\begin{array}{l}\text { 7.Ability to think } \\
\text { critically }\end{array}$ & 0.61 & 0.62 & 0.60 & 0.65 & 0.74 & 0.87 & 1.00 & & & & & & & & & & & & & & \\
\hline 8.Problem solving skills & 0.62 & 0.60 & 0.56 & 0.62 & 0.67 & 0.69 & 0.73 & 1.00 & & & & & & & & & & & & & \\
\hline 9. Time management & 0.51 & 0.44 & 0.42 & 0.37 & 0.44 & 0.55 & 0.51 & 0.60 & 1.00 & & & & & & & & & & & & \\
\hline $\begin{array}{l}\text { 10.Information analysis } \\
\text { and interpretation }\end{array}$ & 0.36 & 0.35 & 0.52 & 0.42 & 0.46 & 0.45 & 0.41 & 0.45 & 0.45 & 1.00 & & & & & & & & & & & \\
\hline $\begin{array}{l}\text { 11. Information } \\
\text { compilation skills }\end{array}$ & 0.32 & 0.27 & 0.40 & 0.30 & 0.33 & 0.43 & 0.45 & 0.43 & 0.32 & 0.66 & 1.00 & & & & & & & & & & \\
\hline $\begin{array}{l}\text { 12. Skills for documenting } \\
\text { ideas and decisions }\end{array}$ & 0.34 & 0.31 & 0.47 & 0.37 & 0.39 & 0.43 & 0.38 & 0.49 & 0.30 & 0.61 & 0.60 & 1.00 & & & & & & & & & \\
\hline 13. Teamwork ability & 0.53 & 0.48 & 0.46 & 0.41 & 0.41 & 0.40 & 0.42 & 0.53 & 0.41 & 0.46 & 0.50 & 0.55 & 1.00 & & & & & & & & \\
\hline $\begin{array}{l}\text { 14.Ability to make } \\
\text { decisions and assume } \\
\text { responsibilities }\end{array}$ & 0.38 & 0.42 & 0.49 & 0.37 & 0.44 & 0.44 & 0.46 & 0.56 & 0.48 & 0.49 & 0.47 & 0.49 & 0.62 & 1.00 & & & & & & & \\
\hline $\begin{array}{l}15 \text {.Ability to work under } \\
\text { pressure }\end{array}$ & 0.37 & 0.40 & 0.36 & 0.35 & 0.35 & 0.39 & 0.45 & 0.51 & 0.38 & 0.40 & 0.38 & 0.41 & 0.46 & 0.56 & 1.00 & & & & & & \\
\hline 16.Leadership ability & 0.39 & 0.42 & 0.38 & 0.35 & 0.41 & 0.43 & 0.50 & 0.44 & 0.38 & 0.37 & 0.37 & 0.37 & 0.52 & 0.59 & 0.64 & 1.00 & & & & & \\
\hline 17.Meeting tight deadline & 0.16 & 0.21 & 0.23 & 0.19 & 0.17 & 0.22 & 0.30 & 0.25 & 0.23 & 0.23 & 0.28 & 0.28 & 0.30 & 0.36 & 0.55 & 0.52 & 1.00 & & & & \\
\hline $\begin{array}{l}\text { 18.Computer technology } \\
\text { competence }\end{array}$ & 0.35 & 0.42 & 0.29 & 0.25 & 0.38 & 0.36 & 0.39 & 0.39 & 0.18 & 0.19 & 0.16 & 0.20 & 0.24 & 0.28 & 0.39 & 0.47 & 0.47 & 1.00 & & & \\
\hline $\begin{array}{l}\text { 19. Accounting software } \\
\text { competence }\end{array}$ & 0.15 & 0.16 & 0.15 & 0.05 & 0.22 & 0.17 & 0.24 & 0.21 & 0.12 & 0.12 & 0.08 & 0.12 & 0.11 & 0.22 & 0.33 & 0.40 & 0.38 & 0.74 & 1.00 & & \\
\hline 20 Research & 0.00 & -0.05 & -0.01 & -0.08 & 0.00 & 0.04 & 0.14 & 0.01 & 0.06 & -0.01 & 0.10 & -0.02 & -0.04 & 0.00 & 0.02 & 0.18 & 0.03 & 0.17 & 0.32 & 1.00 & \\
\hline 21.Risk analysis & 0.09 & 0.08 & 0.22 & 0.13 & 0.13 & 0.04 & 0.07 & 0.13 & 0.09 & 0.16 & 0.01 & 0.11 & 0.07 & 0.12 & 0.11 & 0.10 & -0.01 & -0.01 & -0.04 & 0.12 & 1.00 \\
\hline
\end{tabular}

Table 6. Rotated component matrix ${ }^{\mathrm{a}}$

\begin{tabular}{lccccc}
\hline & \multicolumn{4}{c}{ Component } \\
\cline { 2 - 5 } & 1 & 2 & 3 & 4 & 5 \\
\hline Ability to apply practical knowledge & $\mathbf{0 . 8 7}$ & & & \\
Ability to think logically & $\mathbf{0 . 8 3}$ & & \\
Written Communication skills & $\mathbf{0 . 8 3}$ & & \\
Ability to apply theoretical knowledge & $\mathbf{0 . 8 3}$ & & & \\
Oral Communication skills & $\mathbf{0 . 7 8}$ & & & \\
Ability to think critically & $\mathbf{0 . 7 7}$ & & & \\
Ability to take initiatives & $\mathbf{0 . 7 5}$ & & & \\
Problem solving skills & $\mathbf{0 . 6 9}$ & &
\end{tabular}

Information compilation skills

Skills for documenting ideas and decisions

Information analysis and interpretation

Teamwork ability

Ability to make decisions and assume responsibilities 
Computer technology competence

0.77

Accounting software competence

0.75

Meeting tight deadline

0.75

Leadership ability

0.65

Ability to work under pressure

0.63

Research

0.88

Risk analysis

0.95

\begin{tabular}{lrrrrr}
\hline Eigenvalues & 5.99 & 3.64 & 3.02 & 1.25 & 1.10 \\
\hline \% of Variance (rotation sum) & 28.51 & 17.34 & 14.39 & 5.97 & 5.23
\end{tabular}

Extraction Method: Principal Component Analysis. Rotation Method: Varimax with Kaiser Normalization

SPSS 21 was used to perform the factor extraction on 21 skills using the principal component method and varimax rotation. The results of factor analysis revealed that the Kaiser Meyer Olkin (KMO) is equal to .887 and the Bartlett's test of Sphericity $\left(\chi^{2}=3185.134, p<0.000\right)$ which indicate the suitability of factor analysis and the adequacy of the sample (Field, 2009).

According to the general rule applied in most factor analysis studies (De Lange et al. (2006); Kavanagh and Drennan, (2008); Lin, (2008)) skills with commonalities of greater than 0.51 are included, otherwise the item is excluded on the basis of its low loading. The criterion for the number of factors to be extracted is based on the eigenvalue of one and each factor of the survey has exceeded the acceptable level (0.6) of reliability Cronbach' $\alpha$ (Field, 2009) As a result, five factors were extracted with $70.47 \%$ of the total variance being explained cumulatively.

Table 6 shows the factors which include all the items/variables except time management, which is excluded on the basis of its low loading. The first factor included the largest number of eight items/variables among the five factors, with the eigenvalue of 5.99, and accounts for $28.51 \%$ of the total variance being explained. This factor has Cronbach $\alpha=0.946$ and includes: ability to think logically, written communication skills, ability to apply theoretical knowledge, oral communication skills, ability to take initiatives and problem solving skills. This factor represent the most important factor and combine between two important categories of generic skills as mentioned in IES3 and some studies. The first category is intellectual skills which may consist of ability to apply practical knowledge, ability to think logically, ability to apply theoretical knowledge, ability to think critically, and the ability to take initiatives and problem solving. These items have been classified as intellectual skills in IES3 as well as Awayiga et al. (2010). The second category incuded oral communication and written communication skills. Therefore, the researcher labeled this factor intellectual and communication skills. This result is consistent with some studies such as Kavanagh and Drennan, 2008; Awayiga et al. (2010) and Mandilas et al. (2014) that considered these skills as the most important generic skills.

The second factor with the eigenvalue of 3.64 , accounts for $17.34 \%$ of the total variance and 


\section{MlMacrothink}

International Journal of Accounting and Financial Reporting

ISSN 2162-3082

Cronbach $\alpha=0.860$. Moreover, this factor included five items that combine between information compilation skills, skills for documenting ideas and decisions, information analysis and interpretation are considered by Mandilas et al. (2014) as creative ability skills. The other items: teamwork ability and ability to make decisions and assume responsibilities are interpersonal skills as mentioned in IES3. Therefore the researcher labeled this factor interpersonal and creative ability skills. These results are in line with different studies that support the importance of these skills such as Mandilas et al. (2014); Andrews and Higson (2008) and Lin (2008).

The third factor with the eigenvalue of 3.02 , accounts for $14.39 \%$ of the total variance and Cronbach $\alpha=0.817$. This factor included almost all the items included under the organization skills component of IES 3 such as leadership ability, meeting tight deadline and ability to work under pressure. In addition to IT skills such as computer technology competence and accounting software competence. Therefore the researcher labeled this factor organization skills consistent with IES3. Several studies emphasized the importance of such skills such as Jackling and De Lange (2009); Mandilas et al. (2014) and Abayadeera and Watty (2016).

The fourth factor included only one item, research, and is labelled research skills. Also, the last factor include one item which is risk analysis and could be labeled as analytical skills. Although in this research the last two items are separated in two factors they are combined in other studies (Kavanagh and Drennan (2008); Abayadeera and Watty (2016)) as analytical skills.

Table 7. Component transformation matrix

\begin{tabular}{llrlrr}
\hline Factors & 1 & \multicolumn{1}{l}{3} & \multicolumn{1}{l}{3} & \multicolumn{1}{l}{4} & 5 \\
\hline 1 & .759 & $\mathbf{. 5 2 1}$ & .386 & .017 & .061 \\
2 & -.463 & .056 & $\mathbf{. 8 3 1}$ & .299 & -.060 \\
3 & .458 & -.810 & .200 & .279 & -.125 \\
4 & -.010 & .126 & -.267 & .806 & .514 \\
5 & -.014 & -.231 & .223 & -.429 & .844 \\
\hline
\end{tabular}

Table 7 lists the component transformation matrix of the factor analysis results. Certain correlations exist among the five factors that have been extracted; in particular, the correlation between factor 2 and factor 3 is relatively high and factor 4 and 5 .

\section{Conclusion and Recommendation}

The issue of generic skills has attracted substantial discussion in the academic literature in different developed and developing countries (Kavanagh and Drennan (2008); Jackling and De Lange (2009); Awayiga, Onumah, and Tsamenyi (2010); Bui and Porter (2010); Abayadeera and Watty (2016)). These studies call for greater emphasis on generic skills as preparation for employment in accounting. Moreover, accounting educators worldwide are 


\section{Mll Macrothink}

International Journal of Accounting and Financial Reporting

ISSN 2162-3082

2017, Vol. 7, No. 2

being urged to alter curriculum to provide accounting graduates with a broader set of skills than purely technical accounting skills. Therefore, this research aimed to fill the gap existing in studying generic skills in Egypt by examining the opinions of accounting professionals and students regarding the importance of generic skills.

The generic skills list in the research consists of 21 items/variables and was developed by reference to IES3 and different previous literature Kavanagh and Drennan (2008), Jackling and De Lange (2009) and Mandilas et al. (2014). A comparison is conducted between professionals and students the results indicate significant variations in 11 skills such as oral and written communication, problem solving and teamwork ability. This result is consistent with Kavanagh and Drennan's (2008) study that indicated some agreement between students and practitioners in terms of the importance of some skills. However, there is a difference in terms of how each group ranks each skill.

To increase simplicity and richness to this research's findings, data related to skills were further analyzed using factor analysis and extracted five factors: intellectual and communication, Interpersonal, creative ability, organization, research and analytical skills. These results were consistent with studies by Kavanagh and Drennan, 2008; Awayiga et al. (2010); Mandilas et al. (2014) Andrews and Higson (2008) and Lin (2008). The research results should inform and benefit various groups of stakeholders in Egypt with the needed skills.

This research supported the recommendation developed by Pathway Commission (2012) that a key commitment for every academic accounting program must be keeping a continuous and strong link with accounting profession and keep undergraduate curricula and learning relevant and dynamic. Thus, universities in Egypt should reevaluate their accounting education process and establish strong links with professional accounting firms.

Some studies (Wells et al. (2009); Uyar and Gungormus (2011) support integrating important generic skills into the university level education with the development of learning and assessment strategies that encourage teamwork. Possible solutions to this issue include the use of case studies, real-world problems and internships.

Practitioners viewed universities as being primarily responsible for the poor communication skills of accountants. Thus Siriwardane and Durden (2014) suggested that accounting educators could engage communication specialists to identify the needs and expectations of practicing accountants, accounting educators through accounting program design and innovative teaching methods. In addition, accounting firms and professional may provide generic skills training to their newly employed accounting graduates

This research has a limitation in that it represents a cross-sectional analysis, which involves the analysis of data collected from a study sample at one specific point in time. Thus, future research should apply interviews and focus groups that could provide additional sources of rich data. Moreover, future research could assess the accounting graduates skills developed in public and private university.

Although sampling was random, in an attempt to be representative, the views are not 
revealing of all the views of accounting graduates and professional. Future research exploring the perceptions of accounting academics and accounting students in public university would add to our understanding.

\section{References}

Abayadeera, N., \& Watty, K. (2016). Generic skills in accounting education in a developing country: exploratory evidence from Sri Lanka. Asian Review of Accounting, 24(2), 149-170.

Ahadiat, N., \& Martin, R. M. (2016). Necessary attributes, preparations, and skills for the selection and promotion of accounting professionals. Journal of Accounting and Finance, 16(1), 11. http://dx.doi.org/10.1080/09639280600843369

Albrecht, W. S., \& R. J. Sack. (2000). Accounting Education: Charting the Course through a Perilous Future. Accounting Education Series, 16. Retrieved from http://aaahq.org/pubs/AESv16/toc.htm

Ali, I. M., Kamarudin, K., Suriani, N. A., Saad, N. Z., \& Afandi, Z. A. M. (2016). Perception of employers and educators in accounting education. Procedia Economics and Finance, 35, 54-63.

Andrews, J., \& Higson, H. (2008). Graduate employability, 'soft skills' versus 'hard'business knowledge: A European study. Higher Education in Europe, 33(4), 411-422.

Awayiga, J. Y., Onumah, J. M., \& Tsamenyi, M. (2010). Knowledge and skills development of accounting graduates: The perceptions of graduates and employers in Ghana. Accounting Education: An International Journal, 19(1-2), 139-158.

Boyce, G., Greer, S., Blair, B., \& Davids, C. (2012). Expanding the horizons of accounting education: Incorporating social and critical perspectives. Accounting education, 21(1), 47-74.

Bui, B., \& Porter, B. (2010). The expectation-performance gap in accounting education: an exploratory study. Accounting Education: An International Journal, 19(1-2), 23-50.

Crawford, L., Helliar, C., \& Monk, E. A. (2011). Generic skills in audit education. Accounting Education: An International Journal, 20(2), 115-131.

Daff, L. (2012). Lessons from successes in medical communication training and their applications to accounting education. Accounting Education, 21(4), 385-405.

De Lange, P., Jackling, B., \& Gut, A. M. (2006). Accounting graduates' perceptions of skills emphasis in undergraduate courses: an investigation from two Victorian universities. Accounting \& Finance, 46(3), 365-386.

Elsaadani, M. (2015). Information And Communication Technology Skills'sufficiency Of Egyptian Accounting Graduates. International Journal of Advanced Information Technology, $5(1 / 2)$.

Field, A. (2009). Discovering Statistics Using SPSS: Sage publications. 


\section{Mll Macrothink}

International Journal of Accounting and Financial Reporting

ISSN 2162-3082 2017, Vol. 7, No. 2

Hegazy, S., Sangster, A., \& Kotb, A. (2017). Mapping Forensic Accounting in the UK. Journal of International Accounting, Auditing and Taxation.

International Accounting Education Standards Board. (2015). Framework for International Education Standards For Professional Accountants and Aspiring Professional Accountants.

Jackling, B., \& De Lange, P. (2009). Do accounting graduates' skills meet the expectations of employers? A matter of convergence or divergence. Accounting Education: An International Journal, 18(4-5), 369-385.

Kavanagh, M. H., \& Drennan, L. (2008). What skills and attributes does an accounting graduate need? Evidence from student perceptions and employer expectations. Accounting \& Finance, 48(2), 279-300.

Lin, Z. J. (2008). A factor analysis on knowledge and skill components of accounting education: Chinese case. Advances in Accounting, 24(1), 110-118.

Lin, Z. J., Xiong, X., \& Liu, M. (2005). Knowledge base and skill development in accounting education: Evidence from China. Journal of Accounting Education, 23(3), 149-169.

Maelah, R., Aman, A., Mohamed, Z. M., \& Ramli, R. (2012). Enhancing soft skills of accounting undergraduates through industrial training. Procedia-Social and Behavioral Sciences, 59, 541-549.

Mandilas, A., Kourtidis, D., \& Petasakis, Y. (2014). Accounting curriculum and market needs. Education+ Training, 56(8/9), 776-794.

Mcvay, G. J., Murphy, P. R., \& Wook Yoon, S. (2008). Good practices in accounting education: Classroom configuration and technological tools for enhancing the learning environment. Accounting Education: An International Journal, 17(1), 41-63.

Mohamed, E. K., \& Lashine, S. H. (2003). Accounting knowledge and skills and the challenges of a global business environment. Managerial Finance, 29(7), 3-16.

Nokhal, A., \& Ismail, N. (2014). Mis-alignment between IT knowledge/skills importance and IT knowledge/skills integration level into the accounting curriculum in Egypt. Journal of Financial Reporting and Accounting, 12(1), 45-61.

Normand, C. J., \& Cummings, R. (2015). Screening Criteria for Accounting Positions. Advances in Accounting Education: Teaching and Curriculum Innovations (pp. 149-169). Emerald Group Publishing Limited.

Pathways Commission. (2012). Charting a National Strategy for the Next Generation of Accountants. Retrieved from http://commons.aaahq.org/files/0b14318188/Pathways_Commission_Final_Report_Complete .pdf

Pratama, A. (2015). Bridging the Gap between Academicians and Practitioners on Accountant Competencies: An Analysis of International Education Standards (IES) 


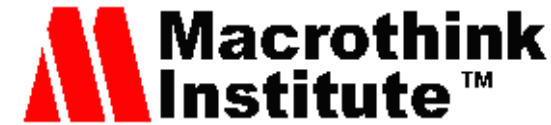

International Journal of Accounting and Financial Reporting

ISSN 2162-3082

Implementation on Indonesia's Accounting Education. Procedia-Social and Behavioral Sciences, 211, 19-26.

Riley, T. J., \& Simons, K. A. (2016). The written communication skills that matter most for accountants. Accounting education, 25(3), 239-255.

Sarea, A. M., \& Alrawahi, F. E. (2014). Bridging the Gap between the Perceptions of Accounting Students and Accounting Practitioners: Evidence from Ahlia University of Bahrain. Jordan Journal of Business Administration, 10(4).

Sergeant, A., \& Camion, D. M. (2016). Critical Thinking Development Through Teaching: A Sample Project in Accounting. Business Education Innovation Journal, 8(2).

Siriwardane, H. P., \& Durden, C. H. (2014). The communication skills of accountants: what we know and the gaps in our knowledge. Accounting Education, 23(2), 119-134.

Towers-Clark, J. (2015). Undergraduate accounting students: prepared for the workplace? Journal of International Education in Business, 8(1), 37-48.

Uyar, A., \& Gungormus, A. H. (2011). Professional knowledge and skills required for accounting majors who intend to become auditors: Perceptions of external auditors. Business and Economics Research Journal, 2(3), 33.

Wally-Dima, L. (2011). Bridging the gap between accounting education and accounting practice: The case of the University of Botswana. IUP Journal of Accounting Research \& Audit Practices, 10(4), 7.

Webb, J., \& Chaffer, C. (2016). The expectation performance gap in accounting education: a review of generic skills development in UK accounting degrees. Accounting education, 25(4), 349-367.

Wells, P., Gerbic, P., Kranenburg, I., \& Bygrave, J. (2009). Professional skills and capabilities of accounting graduates: the New Zealand expectation gap? Accounting Education: An International Journal, 18(4-5), 403-420.

Yong, A. G., \& Pearce, S. (2013). A beginner's guide to factor analysis: Focusing on exploratory factor analysis. Tutorials in quantitative methods for psychology, 9(2), 79-94.

\section{Copyright Disclaimer}

Copyright for this article is retained by the author(s), with first publication rights granted to the journal.

This is an open-access article distributed under the terms and conditions of the Creative Commons Attribution license (http://creativecommons.org/licenses/by/4.0/) 